\title{
Gastric Neoplasm
}

National Cancer Institute

\section{Source}

National Cancer Institute. Gastric Neoplasm. NCI Thesaurus. Code C3387.

A benign or malignant neoplasm involving the stomach. 